\title{
Rural Soldiers Continue to Account for a Disproportionately High Share of U.S. Casualties in Iraq and Afghanistan
}

\author{
WILLIAM O'HAREAND BILL BISHOP
}

$\mathrm{W}$ hen the country goes to war, all Americans are expected to make sacrifices and rural Americans have always stepped forward to do their part in past wars and national emergencies. However, as the data presented here attests, today's rural Americans are making the ultimate sacrifice in disproportionately high numbers. Examination of deaths based on hometown in the Department of Defense records shows soldiers from rural America are dying at a higher rate than soldiers from big cities and suburbs. In most states, soldiers from rural areas ${ }^{1}$ make up a disproportionately high share of casualties.

The high death rate for soldiers from rural areas is linked to the higher rate of enlistment of young adults from rural America. ${ }^{2}$ The higher rate of enlistment in the Armed Forces among rural youth is often linked to diminished opportunities there. ${ }^{3}$ Transitioning from youth to adulthood is more problematic in the rural U.S. because there are fewer job opportunities. For example, the unemployment rate among 18-24-year-olds is 9 percent in rural America compared to 7 percent in urban areas. Among young adults with jobs, those in rural areas are much more likely to be working part-time or in temporary jobs.

Industries that have traditionally sustained rural people and places-farming, timber, mining, fishing and manufacturing-are employing fewer workers than they have in the past. Communities distant from urban areas and with few scenic amenities are struggling with low incomes, a low skill labor force, limited access to services, and weak infrastructure. Competition accompanying globalization increasingly moves jobs overseas or stimulates increased productivity, which in both cases eliminates the "good jobs" that sustain communities and historically promised young people a future.

For decades, rural communities have lamented the loss of young people to urban areas where education and employment opportunities seem brighter. Many who stay, especially in poor areas, are those whose low level of education and skills give them little reason to anticipate better opportunities elsewhere. Enlistment in the Armed Forces can provide rural youth with a path to greater future opportunities that includes gaining new skills and learning about other places and cultures.

As we observe Veteran's Day this year, it is important for Americans to recognize that rural families are paying a disproportionately high price for the wars in Iraq and Afghanistan.

\section{A U T H O R S}

Dr. William P. O'Hare is a Visiting Senior Fellow at the Carsey Institute (bbohare@comcast.net)

BILl BIsHop is a journalist living in Austin, Texas, who is writing a book on political segregation. He is the co-editor of the Daily Yonder, www.dailyyonder.com (bbish@austin.rr.com)

\section{E N D N O T E S}

${ }^{1}$ Here, "rural" refers to nonmetropolitan counties as classified by the U.S. Office of Management and Budget. "Urban" here means "metropolitan," which includes both central cities and their surrounding metropolitan suburbs. We use the metro definitions in place as the time of the first casualty in 2001.

${ }^{2}$ National Priorities Project data on hometowns of active duty army recruits (http://nationalpriorities.org/index.php?option=com_content\&task=view\&id=254 show a distribution between metro and non-metro counties that is similar to the distribution of the hometowns of soldiers who have died in Iraq and Afghanistan. Also, see Kane, Tim. 2005. Who Bears the Burden? Demographic Characteristics of U.S. Military Recruits Before and After 9/11. Heritage Foundation, Center for Data Analysis Report \#05-08. http://www.heritage.org/Research/NationalSecurity/ cda05-08.cfm.

${ }^{3}$ For example, Bachman, Jerald, David Segal, Peter Freedman-Doan, and Patrick O'Malley. 2000. Who Chooses Military Service? Correlates of Propensity and Enlistment in the U.S. Armed Forces. Military Psychology 12 (1): 1-30.

Operation Enduring Freedom (Afghanistan) and Operation Iraqi Freedom have resulted in more than 4,000 military deaths since late 2001. Analysis of these casualties shows:

1,102 of the 4,197 deaths are accounted for by soldiers from rural areas. - Rural areas account for only 19 percent of the adult population, but have suffered 26 percent of the casualties.

- The rural disadvantage is widespread. In 39 states, the rural death rate is higher than the urban death rate.

- The death rate for rural soldiers ( 31 per million adults aged 18 to 59 ) is 48 percent higher than the death rate for big cities and suburbs ( 21 per million)

- Looking only at rural areas, Vermont, Delaware, Nebraska, and Oregon have the highest death rates.

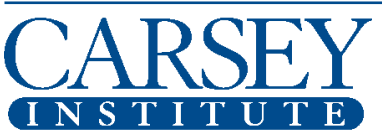

Building KNOWLedge for Families ANd Communities in the 21St Century
Huddleston Hall, 73 Main Street, Durham, NH 03824 (603) 862-2821 • www.carseyinstitute.unh.edu

The Carsey Institute Reports on Rural America are supported by the Annie E. Casey Foundation's initiative to strengthen rural families, Ford Foundation, and the W.K. Kellogg Foundation. 
Table 1. Number of Deaths and Death Rate* of U.S. Soldiers in IraQ and Afganistan Conflicts Based on Whether Their Hometown Was Inside or Outside Metro Areas, by State

\begin{tabular}{|c|c|c|c|c|c|c|}
\hline & \multicolumn{2}{|c|}{ Outside Metropolitan Areas (Rural) } & \multicolumn{2}{|c|}{ Inside Metropolitan Areas (Urban) } & \multicolumn{2}{|c|}{ Total } \\
\hline & $\begin{array}{l}\text { Number of } \\
\text { Deaths }\end{array}$ & Death Rate & $\begin{array}{l}\text { Number of } \\
\text { Deaths }\end{array}$ & Death Rate & $\begin{array}{l}\text { Number of } \\
\text { Deaths }\end{array}$ & Death Rate \\
\hline ALASKA & 11 & 43 & 5 & 27 & 16 & 37 \\
\hline ALABAMA & 24 & 27 & 47 & 24 & 71 & 25 \\
\hline ARKANSAS & 28 & 33 & 29 & 35 & 57 & 34 \\
\hline ARIZONA & 20 & 45 & 77 & 25 & 97 & 28 \\
\hline CALIFORNIA & 24 & 32 & 431 & 20 & 455 & 20 \\
\hline COLORADO & 19 & 35 & 43 & 18 & 62 & 21 \\
\hline CONNECTICUT & 4 & 21 & 27 & 14 & 31 & 14 \\
\hline DC & 0 & NA & 6 & 16 & 6 & 16 \\
\hline DELAWARE & 6 & 60 & 9 & 21 & 15 & 29 \\
\hline FLORIDA & 15 & 21 & 175 & 18 & 190 & 18 \\
\hline GEORGIA & 46 & 28 & 78 & 19 & 124 & 22 \\
\hline HAWAII & 4 & 18 & 15 & 27 & 19 & 24 \\
\hline IOWA & 30 & 32 & 20 & 23 & 50 & 27 \\
\hline IDAHO & 19 & 34 & 11 & 35 & 30 & 34 \\
\hline ILLINOIS & 42 & 37 & 108 & 16 & 150 & 19 \\
\hline INDIANA & 31 & 30 & 70 & 25 & 101 & 26 \\
\hline KANSAS & 26 & 38 & 20 & 20 & 46 & 27 \\
\hline KENTUCKY & 35 & 26 & 32 & 25 & 67 & 26 \\
\hline LOUISIANA & 20 & 30 & 64 & 30 & 84 & 30 \\
\hline MASSACHUSETTS & 0 & 0 & 80 & 20 & 80 & 20 \\
\hline MARYLAND & 11 & 44 & 65 & 20 & 76 & 22 \\
\hline MAINE & 15 & 30 & 14 & 41 & 29 & 35 \\
\hline MICHIGAN & 41 & 37 & 110 & 21 & 151 & 24 \\
\hline MINNESOTA & 22 & 24 & 35 & 15 & 57 & 18 \\
\hline MISSOURI & 38 & 34 & 43 & 17 & 81 & 23 \\
\hline MISSISSIPPI & 37 & 31 & 15 & 25 & 52 & 29 \\
\hline MONTANA & 22 & 49 & 2 & 15 & 24 & 41 \\
\hline NORTH CAROLINA & 33 & 20 & 73 & 20 & 106 & 20 \\
\hline NORTH DAKOTA & 8 & 39 & 10 & 50 & 18 & 45 \\
\hline NEBRASKA & 27 & 57 & 19 & 31 & 46 & 42 \\
\hline NEW HAMPSHIRE & 11 & 35 & 12 & 23 & 23 & 28 \\
\hline NEW JERSEY & NA & NA & 73 & 14 & 73 & 14 \\
\hline NEW MEXICO & 13 & 27 & 22 & 31 & 35 & 30 \\
\hline NEVADA & 8 & 49 & 34 & 26 & 42 & 29 \\
\hline NEW YORK & 28 & 29 & 157 & 14 & 185 & 15 \\
\hline $\mathrm{OHIO}$ & 36 & 27 & 142 & 25 & 178 & 25 \\
\hline OKLAHOMA & 23 & 28 & 45 & 33 & 68 & 31 \\
\hline OREGON & 35 & 56 & 40 & 24 & 75 & 33 \\
\hline PENNSYLVANIA & 45 & 39 & 146 & 23 & 191 & 25 \\
\hline RHODE ISLAND & 2 & 38 & 8 & 13 & 10 & 15 \\
\hline SOUTH CAROLINA & 17 & 23 & 41 & 22 & 58 & 22 \\
\hline SOUTH DAKOTA & 15 & 51 & 4 & 22 & 19 & 40 \\
\hline TENNESSEE & 38 & 33 & 51 & 20 & 89 & 24 \\
\hline TEXAS & 56 & 29 & 326 & 27 & 382 & 27 \\
\hline UTAH & 4 & 11 & 23 & 20 & 27 & 18 \\
\hline VIRGINIA & 21 & 21 & 96 & 25 & 117 & 24 \\
\hline VERMONT & 16 & 61 & 3 & 22 & 19 & 47 \\
\hline WASHINGTON & 16 & 25 & 70 & 21 & 86 & 21 \\
\hline WISCONSIN & 38 & 35 & 48 & 20 & 86 & 25 \\
\hline WEST VIRGINIA & 17 & 26 & 13 & 27 & 30 & 27 \\
\hline WYOMING & 5 & 22 & 8 & 82 & 13 & 40 \\
\hline$\overline{T O T A L}$ & 1,102 & 31 & 3,095 & 21 & 4,197 & 23 \\
\hline
\end{tabular}

* Death rate is the number killed per million population aged 18 to 59

NA means no counties in state are located Outside Metropolitan Areas, except in regards to MA which has no casualties from any of its non-metro counties

Source: Data from the U.S. Department of Defense, 2001 through October 2007. http://siadapp.dmdc.osd.mil/personnel/CASUALTY/castop.htm 